\title{
Context effects in brightness estimation
}

\author{
KARL VAN ORDEN and JOSEPH F. STURR \\ Syracuse University, Syracuse, New York
}

and

\author{
HARVEY A. TAUB \\ V.A. Medical Center, Syracuse, New York, and S.U.N.Y. Health Science Center, Syracuse, New York
}

Under what conditions do briefly presented flashes yield steeper brightness functions than do flashes of longer duration? The brightness of flashes subtending $2^{\circ}$ or $4^{\circ}$ and varying in luminance from .216 to $216 \mathrm{~cd} / \mathrm{m}^{2}$ were judged by magnitude estimation. Only when durations of 10 , 100 , and 1,000 msec were randomly intermixed did the short-duration (10-msec) function have a steeper slope; presenting 10-msec durations alone or intermixing 30-and 1,000-msec durations produced no steepening of the short-duration (10- or $30-\mathrm{msec})$ functions. The steeper brightness functions found for brief flashes in this and previous experiments may be contextually based, that is, dependent upon the presence of longer duration stimuli.

It has generally been found that there are differences in the slopes of brightness functions obtained with shortand long-duration stimuli. Brightness functions of young observers that are derived from flashes of $.5^{\circ}$ or larger and are of moderate and long durations (>60 msec) typically have slopes of .24-.34 (Barlow \& Verrillo, 1976; Ekman \& Künnapas, 1962; Mansfield, 1973; Raab, 1962; J. C. Stevens \& Hall, 1966; S. S. Stevens, 1966). Mansfield (1973) and others (Raab, 1962; J. C. Stevens \& Hall, 1966), however, have found that brightness functions for brief flashes ( $<50 \mathrm{msec}$ ) are steeper, with exponents ranging from .4 to .55 for targets of these sizes. The only exception to the steepening of the brightness function for brief flashes is found in the data of Barlow and Verrillo (1976), who obtained a slope of .24 for both 10- and 1,000-msec stimuli.

Although Barlow and Verrillo's use of a Ganzeld might explain their anomalous result, recent pilot data from our laboratory suggest that other reasons must be explored. We were unable to replicate the findings of a steeper brightness function for briefly presented flashes. An examination of our procedures indicated that, like Barlow and Verrillo (1976), but unlike Mansfield (1973) and others, we presented stimuli of a single duration in a single session rather than intermixing durations. Two series of experiments were undertaken to examine the effect of

Research supported by NIA Grant AG04465 to J.F.S., by the Veterans Administration, and by the Behavioral Research Directorate of the U.S. Army Human Engineering Laboratory. A preliminary report was presented at the October 1985 meetings of the Optical Society of America in Washington, DC. K. Van Orden is now at the Environmental Stress Department of the Naval Medical Research Institute, Bethesda, MD 20814-5055; J. F. Sturr is in the Department of Psychology at Syracuse University; and H. A. Taub is associated with the Psychology Service at the V.A. Medical Center and the Department of Psychiatry at the S.U.N.Y. Health Science Center. this procedural difference on brightness functions for brief flashes.

\section{METHODS}

\section{Subjects}

Forty-two male and 42 female undergraduate students of Syracuse University participated as subjects.

\section{Apparatus}

The stimulus consisted of a circular piece of translucent white glass, $5.5 \mathrm{~cm}$ in diameter, transilluminated by an incandescent bulb housed in a Kodak Ektagraphic Carousel Projector. A three-logunit range of intensity $\left(0.216-216.2 \mathrm{~cd} / \mathrm{m}^{2}\right)$ in 10 steps was provided by Kodak Wratten neutral density filters. Viewing was binocular, and natural pupils were used. A Uniblitz electronic shutter (Vincent Associates) was fitted on the barrel of the projector and controlled by Tektronix Type 161 pulse generators and Type 162 waveform generators to provide flash durations of $10,30,100$, and $1,000 \mathrm{msec}$. In Series 1 , stimuli of 30 and $1,000 \mathrm{msec}$ were used. In Series 2, stimuli of 10,100 , and $1,000 \mathrm{msec}$ were used. Rise and fall times of the stimuli were 1.5 and $3.0 \mathrm{msec}$, respectively. A 700-msec warning tone preceded the flash by $950 \mathrm{msec}$. Four small red fixation LEDs were left on continuously throughout the experimental session. The stimuli appeared in the center of the fixation lights. Luminance was calibrated by a Tektronix J6523 narrowangle luminance probe, and duration was calibrated by a photocell and an oscilloscope.

\section{Procedure}

Subjects were seated either 79 or $158 \mathrm{~cm}$ from the stimulus, which thus subtended a visual angle of $4^{\circ}$ or $2^{\circ}$. Stimuli were presented every $30 \mathrm{sec}$. Each intensity $\times$ duration combination was presented once. Stimulus intensities were randomized for every subject, with the restriction that the brightest stimulus never followed the dimmest, and vice versa. The first two stimuli in any session were repeated at the end of the session, and the last estimates given to them by the subjects were taken as the data for those stimuli. Sessions lasted approximately 30 to $45 \mathrm{~min}$ per subject. Table 1 describes the groups and conditions for each experiment.

Following the presentation of each flash, the subjects verbally reported the number they believed matched the brightness of the 
Table 1

Stimulus Conditions and Results for Series 1 and Series 2

\begin{tabular}{|c|c|c|c|c|c|c|c|}
\hline Experiment & $\begin{array}{l}\text { Status of } \\
\text { Duration } \\
\text { Variable }\end{array}$ & $N$ & $\begin{array}{c}\text { Dark } \\
\text { Adaptation } \\
\text { Time } \\
\text { (min) }\end{array}$ & $\begin{array}{l}\text { Stimulus } \\
\text { Size }\end{array}$ & $\begin{array}{c}\text { Stimulus } \\
\text { Durations } \\
\text { (msec) }\end{array}$ & $\begin{array}{l}\text { Mean } \\
\text { Slope }\end{array}$ & $\begin{array}{c}\text { Significance } \\
\text { of Difference }\end{array}$ \\
\hline \multicolumn{8}{|c|}{ Series 1} \\
\hline 1 & $\begin{array}{l}\text { Between } \\
\text { Subjects }\end{array}$ & $\begin{array}{l}\text { 10(Group 1) } \\
\text { 10(Group 2) }\end{array}$ & $\begin{array}{l}10 \\
10\end{array}$ & $\begin{array}{l}4^{\circ} \\
4^{\circ}\end{array}$ & $\begin{array}{r}30 \\
1,000\end{array}$ & $\begin{array}{l}.26 \\
.31\end{array}$ & n.s. \\
\hline 2 & $\begin{array}{l}\text { Within } \\
\text { Subjects }\end{array}$ & 10 & 10 & $4^{\circ}$ & $\begin{array}{r}30 \\
1,000\end{array}$ & $\begin{array}{l}.36 \\
.33\end{array}$ & n.s. \\
\hline 3 & $\begin{array}{l}\text { Within } \\
\text { Subjects }\end{array}$ & 10 & 20 & $4^{\circ}$ & $\begin{array}{r}30 \\
1,000\end{array}$ & $\begin{array}{l}.36 \\
.35\end{array}$ & n.s. \\
\hline \multicolumn{8}{|c|}{ Series 2} \\
\hline 4 & & 14 & 10 & $2^{\circ}$ & 10 & .31 & \\
\hline 5 & $\begin{array}{l}\text { Within } \\
\text { Subjects }\end{array}$ & 14 & 10 & $2^{\circ}$ & $\begin{array}{r}10 \\
100 \\
1,000\end{array}$ & $\begin{array}{l}.38 \\
.29 \\
.28\end{array}$ & $\begin{array}{l}10 \text { vs. } 100^{*} \\
10 \text { vs. } 1,000^{*}\end{array}$ \\
\hline 6 & $\begin{array}{l}\text { Within } \\
\text { Subjects }\end{array}$ & 16 & 10 & $4^{\circ}$ & $\begin{array}{r}10 \\
100 \\
1,000\end{array}$ & $\begin{array}{l}.38 \\
.28 \\
.31\end{array}$ & $\begin{array}{c}10 \text { vs. } 100^{*} \\
10 \text { vs. } 1,000 \text { n.s. }\end{array}$ \\
\hline
\end{tabular}

${ }^{*} p<.05$.

flash. All subjects were restricted to positive numbers (fractions or wholes), and no standard or modulus was imposed; that is, the method of absolute magnitude estimation was employed (Hellman \& Zwislocki, 1961).

\section{SERIES 1}

There were three experiments in Series 1. In Experiment 1, duration was a between-subjects variable: Groups 1 and 2 judged the brightness of 30 - and $1,000-\mathrm{msec}$ stimuli, respectively. In Experiments 2 and 3, duration was a within-subject variable: 30 - and 1,000 -msec stimuli were randomly intermixed in a given session. Subjects in Experiments 2 and 3 were instructed to ignore changes in duration and to match numbers only to the brightness of the flash, as was the procedure in the Mansfield (1973), Raab (1962), and J. C. Stevens and Hall (1966) studies. The length of dark adaptation was $10 \mathrm{~min}$ in Experiments 1 and 2 and 20 min in Experiment 3.

\section{Results}

A straight line was fit to the log stimulus intensity and $\log$ brightness estimates of each subject by the method of least squares. This method produced power functions whose slopes were subjected to a sex $\times$ group analysis of variance in Experiment 1 and sex $\times$ duration analyses of variance in Experiments 2 and 3. None of the variables or their interactions showed significant effects. The mean slopes are reported in Table 1 . The mean $r^{2}$ values from the least squares fit of these individual functions ranged from .88 to .98 , with a mean of .94 .

\section{SERIES 2}

In the experiments in Series 1 , presenting 30 - and $1,000-\mathrm{msec}$ stimuli either separately or randomly mixed did not cause a steeper slope for the shorter duration. Although Mansfield (1973) found that the 30-msec stimulus was within the range of short durations that produced the steeper slope, the data from Raab (1962) and J. C. Stevens and Hall (1966) suggest that durations shorter than $30 \mathrm{msec}$ might be necessary for a consistent demonstration of the steepening effect. The second series thus used a 10-msec stimulus and compared this with stimuli that were one or two log units longer in duration. In Experiment 4, the 10-msec stimulus was presented alone. In Experiments 5 and 6, 10-, 100-, and 1,000-msec stimuli were randomly intermixed in a single session. For Experiments 4 and 5 , the stimulus size was $2^{\circ}$, the same as that used by J. C. Stevens and Hall (1966); in Experiment 6, it was $4^{\circ}$, as in Series 1. Conditions in Series 2 are displayed in Table 1. As in Series 1, the subjects were instructed to ignore changes in duration and to judge only the brightness of the flash.

\section{Results}

Individual power functions for brightness were again constructed for each subject under each condition, producing slope values for the subsequent analyses. The mean slopes for all experiments in Series 2 are reported in Table 1 . The mean $r^{2}$ values ranged from .93 to .98 with a mean of .95 .

Comparisons of the slope of the 10 -msec function of Experiment 4 with the 1,000-msec slopes of the experiments in Series 1 showed that there was no steepening of slope when the short-duration stimulus was presented alone. Similarly, the slope of the $10-\mathrm{msec}$ brightness function in Experiment 4 was not significantly different from the slopes of the 100- and 1,000-msec functions from Experiments 5 and 6 .

A sex $\times$ duration analysis of variance on the slopes in 
Experiment 5 indicated that the only significant factor was the main effect of duration $[F(2,24)=11.22$, $p<.0005]$. Further analysis by a Dunn's multiple comparison indicated that the 10-msec brightness function was significantly steeper than both the $100-\mathrm{msec}[\mathrm{tD}(3,24)=$ $2.81, p<.05]$ and the $1,000-\mathrm{msec}[t \mathrm{D}(3,24)=2.99$, $p<.05]$ brightness functions.

The analysis for Experiment 6 again indicated that only the main effect of duration was significant $[F(2,28)=$ $8.40, p<.005$ ]. The Dunn's procedure found the 10 msec brightness function to be steeper than the $100-\mathrm{msec}$ function $[t \mathrm{D}(3,28)=2.85, p<.05]$, but not significantly steeper than the 1,000 -msec function $[t \mathrm{D}(3,28)=1.89$, $p>.05]$.

\section{DISCUSSION}

The results for Series 1 show no significant steepening of the slope for the 30-msec flashes, either when they were presented alone or when they were randomly mixed with the $1,000-\mathrm{msec}$ stimuli. The results for Series 2 show no steepening of the slope for the 10 -msec flashes when they were presented alone. However, with both the $2^{\circ}$ and $4^{\circ}$ sizes, there was a significant steepening when the $10-\mathrm{msec}$ stimuli were randomly intermixed with the 100 - and 1,000 -msec stimuli. These results support the Barlow and Verrillo (1976) study, which shows that when brief flashes are presented alone, the resulting brightness function is no different from functions derived from longer duration stimuli. These results also suggest that the steeper functions for brief stimuli found by Mansfield (1973) and others (Raab, 1962; J. C. Stevens \& Hall, 1966) can be obtained only when flashes of short, medium, and long duration are randomly mixed in a session. Even though subjects in the studies that intermixed durations were instructed to ignore changes in stimulus duration and estimate only the brightness of a given flash, the current results indicate that subjects' judgments are influenced by the context of other stimuli.
The brightness functions obtained for the 10 -msec flashes in Experiments 5 and 6 were in general flatter than those obtained by previous investigators who had intermixed durations. We speculate that this difference may be due to the greater number of durations used in the previous studies. Mansfield (1973) intermixed durations of $1,3,10,30,100,200,300$, and $1,000 \mathrm{msec}$. Likewise, J. C. Stevens and Hall (1966) and Raab (1962) intermixed 11 and 12 durations, respectively. The potential requirement for 3 or more randomly mixed durations may also explain our failure to obtain a steepening with the 30 -msec stimulus in Series 1 when only two durations were intermixed.

In summary, the findings suggest that there may be differences in slopes of brightness functions for shortduration stimuli as a function of whether they are rated alone or as part of a series intermixed with other durations. Although the current findings demonstrate this context effect, the relative significance of any of the factors that may have influenced it will have to be evaluated in a future study.

\section{REFERENCES}

BARLOW, R. B., JR., \& VERRILLO, R. T. (1976). Brightness sensation in a ganzfeld. Vision Research, 16, 1291-1297.

EkMaN, G., \& KüNNAPAS, T. (1962). Brightness of monochromatic light in scotopic and photopic vision. Joumal of Psychology, 53, 319-327.

Hellman, R. P., \& ZwislockI, J. (1961). Some factors affecting the estimation of loudness. Journal of the Acoustical Society of America, 33, 687-694.

MANSFIELD, R. J. W. (1973). Brightness function: Effect of area and duration. Journal of the Optical Society of America, 63, 913-920.

RAAB, D. H. (1962). Magnitude estimation of the brightness of brief foveal stimuli. Science, 135, 42-44.

STEvens, J. C., \& HALl, J. W. (1966). Brightness and loudness as functions of stimulus duration. Perception \& Psychophysics, 1, 319-327.

Stevens, S. S. (1966). Duration, luminance, and the brightness exponent. Perception \& Psychophysics, 1, 96-100.

(Manuscript received July 28, 1986; revision accepted for publication January 18, 1987.) 